\title{
Rastros da memória na doença de Alzheimer: entre a invenção $e$ a alucinação
}

DoI

http://dx.doi.org/10.11606/ 2179-0892.ra.2017.137321

\section{Daniela Feriani}

- Universidade Estadual de Campinas / Campinas, SP, Brasil

$\checkmark$ danielaferiani@yahoo.com.br

RESUMO

O artigo discute como a memória se constitui numa relação tensa e ambígua entre imaginação e alucinação, juventude e velhice, normal e patológico ao longo da composição da doença de Alzheimer. Se a bibliografia mostra como o processo mnemônico não se dá de maneira cronológica e linear, mas como sobreposição e emaranhado temporal, cabe se perguntar quando esse processo se torna patológico. A partir de noções como trauma, verdade contrafactual e alucinação, o artigo percorre os diferentes significados, contextos e usos da memória.

\section{PALAVRAS-ChAVE}

Doença de Alzheimer, memória, alucinação, casa, tempo. 
De repente, algo aparece. Por ejemplo: una puerta se abre, una mariposa pasa batiendo sus a las. Basta con esta nada. El pensamiento ya advierte el peligro. Para empezar, corre el riesgo de equivocarse creyendo apropiarse de que acaba de aparecer y absteniéndose de considerar que viene luego, que no es sino desprendimiento, desaparición. Porque es un errar creer que una vez aparecida, la cosa está, permanece, resiste, persiste tal cual en el tiempo como en nuestro espíritu, que la describe y conoce. Bien sabemos que no es nada: una puerta no se abre sino para cerrarse en un momento u otro; una cosa, una mariposa, no aparece sino para desaparecer al instante.

(Georges Didi-Huberman. La imagen mariposa). ${ }^{7}$
1 Este texto é parte de minha tese de doutorado em Antropologia denominada Entre sopros e assombros: estética e experiência na doença de Alzheimer, financiada pela Fundação de Amparo à Pesquisa do Estado de São Paulo (Fapesp).

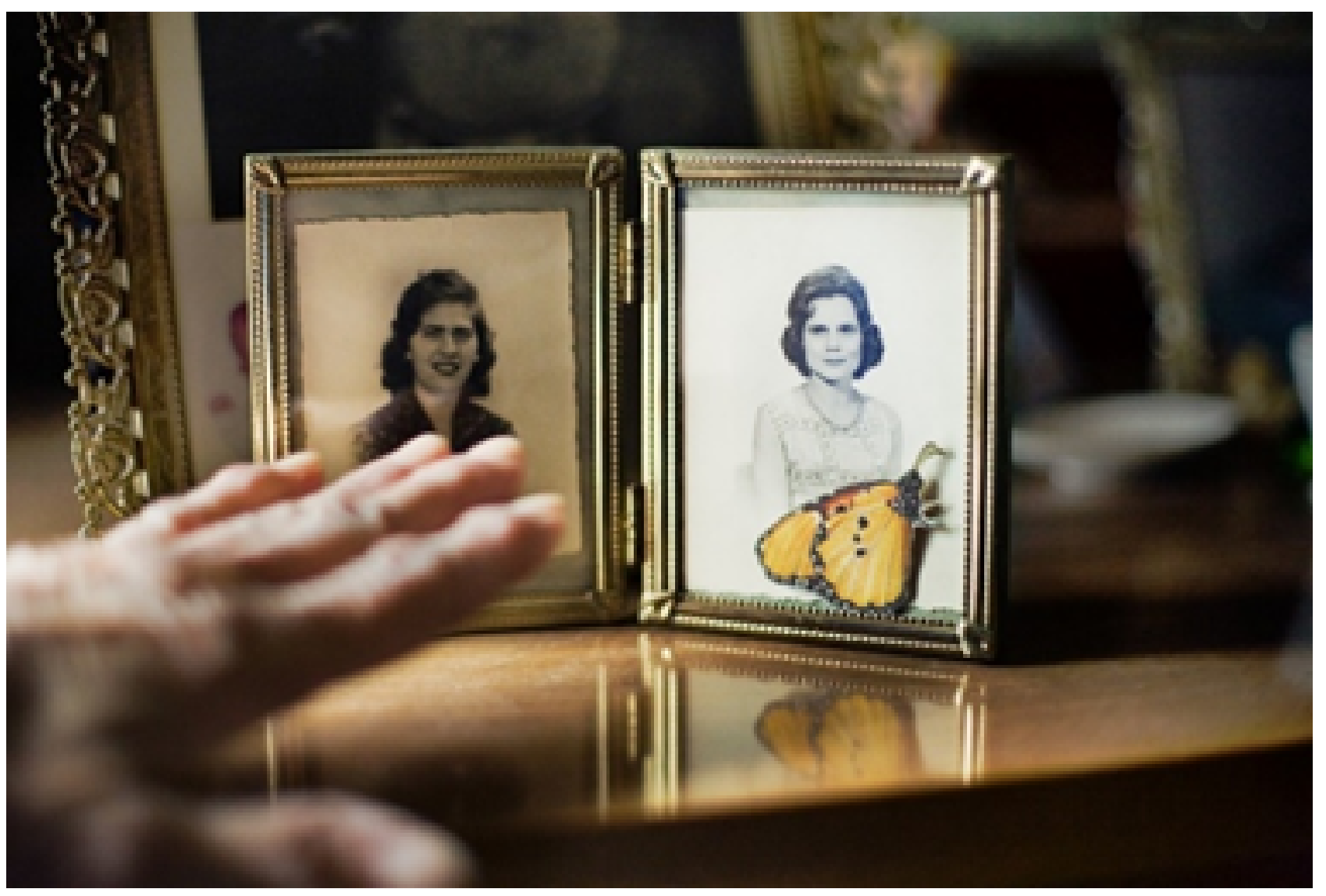

Na consulta de neurologia de um hospital universitário, Eliseu, que cuida da esposa, Olga, disse ao residente:

Ela tá com problema que quer voltar, quer voltar... Voltou 30 anos a trás, quando a gente morava em São Paulo. Ela faz mala e quer sair de casa, diz que vai pra casa dela, de 30 anos atrás. (...) Teve um dia que ela achou as chaves, abriu 0 armário de roupas e tirou tudo de lá e colocou tudo em malas... Eu a té peguei um álbum de fotos pra mostrar a ou tra casa que a gente construiu, pra dizer que não tem mais, que o trator passou por cima..."

\section{Figura 1}

Ensaio fotográfico "Crace", de Susan Falzone, que fotografou a tia com doença de Alzheimer. Para mais informações ver: http://www.hypeness. com.br/2014/04/fotografocapta-o-cotidiano-da-tiacom-alzheimer-em-seriesombria-e-emocionante/e http://susanfalzone.com/ 
Passei uma tarde com Olga e Eliseu, na casa deles. Perguntei se ela gostava de morar naquela casa. Ela disse que gostaria de morar lá, que o marido também gostaria, mas que não dava porque eles trabalhavam em outra cidade, dizendo o nome da cidade onde nasceram, conheceram-se e se casaram. "Então fica difícil porque é muito longe". Eu percebi a confusão e concordei. Ela continuou: "até que a casa [apontando a casa onde estávamos] ficou boa, foi reformada, daria até pra morar nela, mas é muito longe". Em outro momento, Olga chegou a perguntar se eu morava ali, naquela casa. ${ }^{2}$

Eunice também insiste em "querer ir pra casa", referindo-se à casa onde morava até os primeiros sinais de esquecimentos serem notados pela família. Desde então, há um ano e meio, ela mora no apartamento em frente ao da filha, em outra cidade. Contou Sílvia:

Às vezes minha mãe toca a campainha de casa com a mala pronta e diz que vai pra casa. No começo eu batia de frente, mas fui aprendendo a lidar com a situação. Hoje não faço mais isso. Quando ela diz que vai pra casa, eu digo "ok, mas antes vamos jantar". Eaí, enquanto ela janta, eu desfaço a mala e guardo. Depois do jantar, ela já se esqueceu do assunto.

Esses relatos e cenas compõem parte de minha pesquisa sobre a constituição de um campo de experiências, imagens e disputas na doença de Alzheimer, na qual acompanhei consultas nos ambulatórios de neurologia e psiquiatria geriátrica de um hospital universitário, reuniões do grupo de apoio aos cuidadores-familiares da Associação Brasileira de Alzheimer (ABRAz), além de visitar famílias e recolher imagens sobre a doença disponíveis na internet, como ensaios fotográficos, vídeos e campanhas de conscientização, blogs escritos por pessoas em processo demencial e autorretratos de um artista com a doença. Neste artigo, parto de uma das principais queixas do cuidador-familiar - a do doente "querer ir pra casa" - para percorrer como a memória se dobra e desdobra ao longo da composição da doença de Alzheimer, em um emaranhado de relações, torções e sobreposições entre demência e lucidez, lembrança e esquecimento, imaginação e alucinação, juventude e velhice, normal e patológico. Se, como alguns autores vão mostrar, a memória é intricação, montagem, rastro, um jogo de ausência e presença, cabe se perguntar como isso se mostra numa doença cujos fios vão se soltando aos poucos. ${ }^{3}$

A memória dos locais, ou o testemunho das pedras e ruínas, abre a possibilidade de ver os lugares não só como depositários mas também como portadores de recordações (os locais como sujeitos), ampliando a memória dos indivíduos à memória da família, quando se trata de tomar a casa como um desses espaços, através do vínculo entre gerações, tanto as presentes quanto as ausentes.
2 Em outra ocasião,

Olga disse que estávamos em 1963 - o ano era 2014
3 "É como se os fios fossem se soltando aos poucos": era assim que a coordenadora da Associação Brasileira de Alzheimer (ABRAz) começava a explicar a doença nas reuniões do grupo de apoio aos cuidadores-familiares. 
Assmann (2011) chama esses lugares de "locais de gerações" ou "locais da família", estruturados a partir de um "princípio do arraigamento".

Seixas mostra como, em Bergson e Proust, a memória existe "fora de nós": ela está "inscrita nos objetos, nos espaços, nas paisagens, nos odores, nas imagens, nos monumentos, nos arquivos, nas comemorações, nos artefatos e nos lugares mais variados" (ênfase original, 2004: 51-52). Concordando com vários outros críticos, o autor argumenta que há uma dimensão espacial do tempo proustiano, ou seja, não se trata de buscar apenas um tempo perdido, mas, também e concomitantemente, um espaço perdido, dos lugares idos e vividos. A memória também encontraria esses espaços, percorrendo, entrelaçando e (re)criando os fios, as trajetórias, as trilhas entre eles.

Se a memória é central para a tessitura da doença de Alzheimer, ela, porém, não basta. É percorrendo o dia a dia do doente através de cenas e relatos descritos por quem cuida que residentes e médicos conseguem perceber o quanto o "não lembrar" está relacionado ao "não conseguir fazer" da doença. Esqueceu de tomar banho ou não sabe mais como fazer? Esqueceu de pagar conta ou não consegue? É quando atividades domésticas, como tomar banho, pagar contas, vestir-se, cozinhar, fazer supermercado, estão afetadas que surge a hipótese de demência.

Na busca por um diagnóstico, que se revela um caminho tortuoso, cheio de tropeços, dúvidas e cruzamentos, os médicos enfatizam, em aulas e discussões de caso $^{4}$, que é preciso ir além da memória. ${ }^{5}$ Um neurologista, após ouvir a residente dizer que a paciente esquece como cozinhar e só se lembrou de 4 nomes de animais, chamou-lhe a atenção: "viu como a gente tem mania de achar que tudo é memória? A gente vê como problema de memória e não de linguagem, cognição". Em outra consulta, esse médico comentou com a residente:

A questão é que o paciente ou o familiar sempre fala de memória: "ah, ele esquece de dar descarga" [uma das queixas trazidas pelo familiar]; provavelmente não é esquecimento, mas mais alteração de comportamento, desleixo com a higiene pessoal. Se perde o caminho, falam que ele esqueceu... Mas nem sempre é isso; a confusão nem sempre é esquecimento.

Se, no compósito de relações que compõem a doença de Alzheimer, ela é diferenciada das demais demências principalmente pela perda da memória, sobretudo quando se trata de chegar a um diagnóstico, experimentá-la passa muito mais pela estranheza e desorientação dos comportamentos, que pode ou não estar associado com a perda da memória ou, ainda, estar na dobra entre memória e alucinação - a memória que alucina, o cotidiano que se assombra. É essa dimensão que parece mais incomodar os cuidadores-familiares: mais que
4 Discussão de caso é uma expressão usada por médicos e residentes para designar as investigações e conversas entre eles na busca por um diagnóstico.

5 Discuto a composição do diagnóstico em "Pistas de um cotidiano assombrado: a saga do diagnóstico na doença de Alzheimer" (Feriani, 2017). 
a perda de memória, são as situações consideradas "sem noção" as que mais mobilizam queixas, como vestir uma camisa como se fosse calça, não conseguir ligar a máquina de lavar roupa, mudar o canal da televisão com um chinelo, usar detergente para cozinhar, achar que os alimentos da geladeira vão atacá-lo, convidar a imagem do espelho para passear.

O "querer ir pra casa" é tanto desorientação temporal quanto espacial, a vivência de um "tempo outro" e de um "mundo outro". Na doença de Alzheimer, o lembrar-esquecer se emaranha com o aparecer-desaparecer. Afinal, são lembranças ou visões? A obscuridade - tanto epistemológica quanto ontológica - da doença faz dela um "meio de aparição" (Didi-Huberman, 2013), "uma força social fantasmagórica", uma "atuação recíproca da verdade e da ilusão" (Taussig, 1993: 126), estando entre a fabulação e a incerteza, a história e a imaginação, a realidade e a ficção. Em um movimento de sístole e diástole, a memória tanto contém quanto transborda, é excesso e falta, constitui a doença de Alzheimer ao mesmo tempo em que é insuficiente.

\section{ESQUECER, NA ERA DA MEMÓRIA; LEMBRAR, NA ERA DO ESQUECIMENTO}

\author{
Sóse fala tanto de memória \\ porque ela já não existe mais \\ (Pierre Nora, Entre história \\ e memória)
}

A partir da ideia de David Harvey da passagem da modernidade para a pós-modernidade, nos anos 80, Leibing (2000) aponta a falta de memória como um dos grandes sinais dos "novos tempos" através da proclamação de um "fim da história". Na psiquiatria, isso pode ser visto no surgimento de novos conceitos, como "transtorno de personalidade múltipla" para casos de abuso sexual, e "transtorno de estresse pós-traumático" para experiências de guerra. Para a autora, a doença de Alzheimer é mais um exemplo de uma forma do esquecimento patológico, mas que, diferentemente dos outros dois, não tem, de acordo com o entendimento psiquiátrico, uma etiologia social, mas orgânica, além da perda da memória ser progressiva e irrecuperável.

$\mathrm{Na}$ tentativa de apreender o intercâmbio entre biologia e cultura, Leibing se propõe a pensar no contexto histórico que possibilitou a emergência da

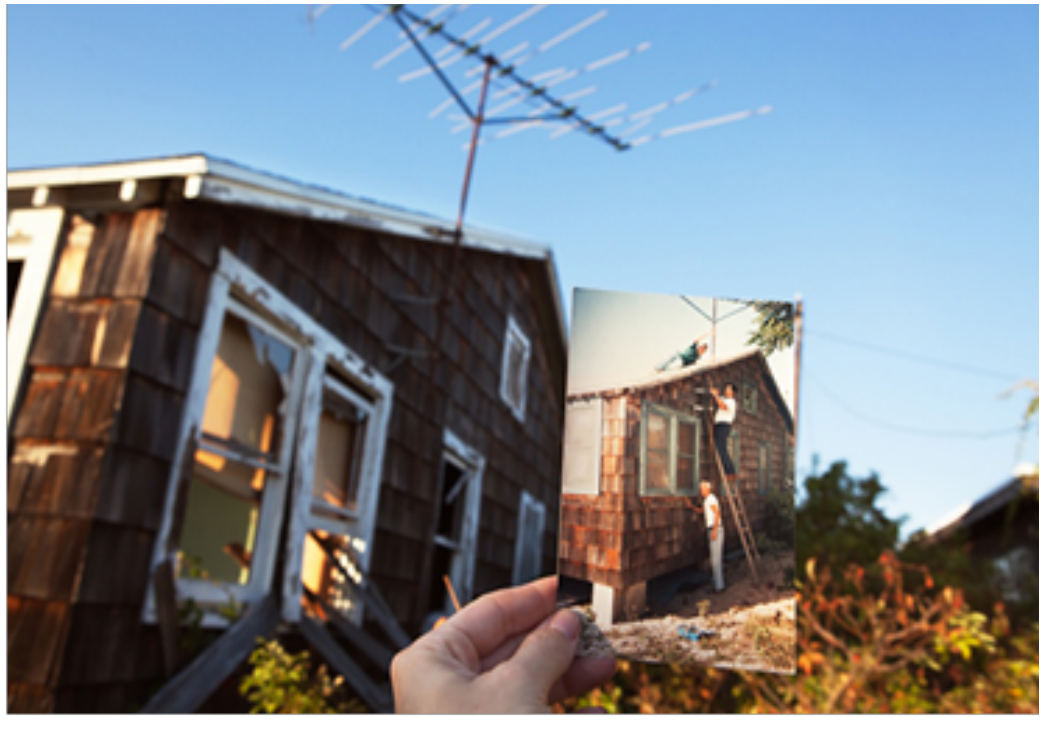

Figura 2

Ensaio fotográfico "Crace", de Susan Falzone, que fotografou a tia com doença de Alzheimer. 
doença de Alzheimer como o "mal do século", refletindo sobre o significado da memória nas sociedades pós-modernas. Partindo de uma análise histórica sobre a doença, a autora mostra que, da descoberta, em 1906, aos dias atuais, houve períodos de invisibilidade e visibilidade da mesma, os quais devem ser compreendidos a partir dos paradigmas dominantes em cada época. Assim, o período de "redescoberta" da doença de Alzheimer, a partir dos anos 80, está ligado a uma preocupação com a memória. Desse modo, Leibing afirma que o aumento dos casos de Alzheimer não pode ser explicado apenas pelo enveIhecimento da população, mas que a doença é uma "criança de seu tempo", para usar uma expressão da autora. Em outras palavras, tem algo no contexto atual - nos "tempos pós-modernos" - que pode explicar a emergência e visibilidade da doença. A doença de Alzheimer resultaria, assim, dos tempos modernos em crise com sua memória.

Para Walter Benjamin, em "Experiência e pobreza”, de 1933, e "O narrador", escrito entre 1928 e 1935, o mundo contemporâneo ou moderno, no qual há ascensão da técnica e do romance (e a consequente valoração do indivíduo), caracteriza-se por um empobrecimento da experiência comunicável, aquela transmitida pela narrativa - e pela memória, já que, para ele, esta é a "musa da narrativa", a que "funda a cadeia da tradição", transmitindo o conhecimento de geração em geração. Uma referência importante para Benjamin é a guerra mundial, da qual os combatentes voltaram mudos, mais pobres em experiências comunicáveis - apesar de viverem uma forte experiência, ela não pôde ser assimilada por palavras.

Para Gagnebin, Benjamin esboça a "ideia de uma outra narração, uma narração nas ruínas da narrativa, uma transmissão entre os cacos de uma tradição em migal has" (2004: 90). Tal proposição nasceria de uma "injunção ética e política" de "não deixar o passado cair no esquecimento". Não se trata de construir uma grande narrativa épica, heroica, mas de colocar o narrador numa posição mais humilde, menos triunfante - o narrador seria a figura do "catador de sucata e lixo, esse personagem das grandes cidades modernas que recolhe os cacos, os restos, os detritos, movido pela pobreza, certamente, mas também pelo desejo de não deixar nada se perder". A narrativa, portanto, teria se transformado - não mais a da história oficial, dos grandes feitos, mas o "narrador sucateiro" deveria "apanhar tudo aquilo que é deixado de lado como algo que não tem significação, algo que parece não ter nem importância nem sentido, algo com que a história oficial não saiba o que fazer" (Gagnebin, 2004: 90).

Para Benjamin, ainda de acordo com Gagnebin, "os elementos de sobra do discurso histórico" são o sofrimento - o "sofrimento indizível" da grande guerra, "a experiência inenarrável do horror" dos campos de concentração-e 
aquilo que não tem nome, aqueles que não têm nome, o anônimo, aquilo que não deixa nenhum rastro, aquilo que foi tão bem apagado que mesmo a memória de sua existência não subsiste, aqueles que desapareceram tão por completo que ninguém se lembra de seu nome (Gagnebin, 2004: 90).

Trata-se de uma tarefa paradoxal de transmitir o inenarrável. E a nova narrativa não poderia ser contínua, num desenrolar tranquilo e linear. Ela deve, como rememoração ao invés de comemoração, abrir-se aos brancos, aos buracos, ao esquecido, ao recalcado, aos solavancos, à incompletude, "aquilo que ainda não teve direito nem à lembrança nem às palavras". A nova narrativa também precisa estar atenta ao momento atual, "particularmente a estas estranhas ressurgências do passado no presente, pois não se trata somente de não se esquecer do passado, mas também de agir sobre o presente" (Gagnebin, 2004: 91).

Assmann, ao percorrer a ambivalência do excesso e da falta, perpassa as mais diferentes perspectivas sobre o tema, fazendo dialogar filosofia, literatura, teoria da história, psicanálise, egiptologia e teoria da arte. Posicionando-se contra uma crise da memória, a autora argumenta que o que vemos é o desmantelamento de uma "síntese abstrata de uma história em particular" em "muitas memórias diferentes e parcialmente conflitantes que tornam efetivo seu direito de reconhecimento na sociedade" (2011: 20). Nunca houve tanto interesse pela memória e o tema mobiliza as mais diferentes áreas do conhecimento, da robótica à neurologia, sendo "um fenômeno que nenhuma disciplina pode monopolizar" (2011: 20). Além de transdisciplinar, a memória é um tema controverso dentro de cada disciplina.

Seguindo um percurso histórico, Assmann mostra como, na Antiguidade, fez-se uma primeira diferenciação entre memória como "arte" (ou técnica) ${ }^{6} \mathrm{e}$ memória como "potência". Se, para a primeira, o que importa é o armazenamento e o ato de decorar como formas de combater o tempo e o esquecimento, havendo uma correspondência entre o que foi arquivado e o que foi recuperado, na segunda é a recordação, o ato de lembrar que se destaca, sendo a diferença entre o que foi arquivado e sua recuperação o que vem à tona, tendo, portanto, a interferência do tempo no processo da memória.

O deslocamento da noção de memória de armazenamento para recordação permitiu pensá-la como um processo não cronológico: não se trata de um movimento linear e contínuo, do passado para o presente e para o futuro, mas como um movimento espiralar no qual o que há de mais próximo pode se tornar mais distante e o que está mais distante, mais próximo, "às vezes próximo demais" (Assmann, 2011: 359).

Na doença de Alzheimer, o passado ganha uma proximidade tão significativa que ele se confunde com o próprio presente. Tal emaranhado se tece através
6 Sobre a memória como arte e as transformações da técnica de memorizar, desde os oradores gregos, passando pela Idade Média, Renascimento e chegando ao método científico do século XVII, ver Yates (2010). 
da anulação da distância temporal e espacial entre passado e presente, tornando presente o ausente, e ganha contornos patológicos a partir de sintomas como alucinação, confabulação e delirium. A não cronologia do processo mnemônico assume conteúdos específicos quando passamos de um estado saudável para um processo mnemônico tido como patológico. Se a não linearidade faz parte da própria memória, o que faz com que ela se torne patológica?

Assim como a memória não é contínua, a doença também não é. "Não se é demente o tempo todo". Essa foi uma fala do médico neurologista durante uma discussão de caso em que, após conversar com a paciente para investigar um possível sintoma alucinatório, percebe uma preservação da capacidade interativa e de julgamento da mesma: a paciente, quando perguntada onde estavam os pais, diz que os mesmos já "tinham ido", sendo que o marido e a filha contaram, na consulta, que, no dia anterior, ela tinha dito que os pais dela tinham ido visitá-la e levaram um bolo de chocolate. Assim como a memória se dá por saltos e sobressaltos, também estão previstos, na demência, lampejos de consciência.

Bergson fala em lembrança-hábito e lembrança-imagem; Proust, em memória voluntária e memória involuntária. A lembrança-imagem e a memória involuntária seriam a memória espontânea, a memória por excelência, a memória que imagina, aquela que nos arremata/atravessa (como quando Proust sente o cheiro da madeleine e é arremessado ao passado). Já a lembrança-hábito e a memória voluntária são a memória factual, intelectual, um hábito esclarecido pela memória, uma memória aprendida, adquirida e impessoal, não atingindo o estatuto pleno da memória, sendo uma memória menor, corriqueira, superficial. O passado verdadeiro seria o que não passa por um esforço intelectual de o apreender, mas pelas sensações que despertam em nós a despeito de nossa vontade.

Segundo Seixas, a memória verdadeira se dá por imagens que nos aparecem e somem por "lampejos bruscos"; é instável, descontínua e ela "não vem para preencher os espaços em branco", mas "supõe as lacunas e constrói-se com elas (...) ainda que a integralidade do passado esteja irremediavelmente perdida, aquilo que retorna vem inteiro, íntegro porque com suas tonalidades emocionais e 'charme' afetivo" (2004: 47). Já a memória voluntária - ou a lembrança-hábitodeixaria escapar a dimensão afetiva e descontínua da vida.

A diferenciação entre lembrança-hábito e lembrança-imagem, em Bergson, e entre memória voluntária e memória-involuntária, em Proust, pode ser boa para pensar na diferenciação entre saber/conseguir fazer (funcionalidade) e lembrar (memória) reivindicada nas consultas que eu acompanhei. Para os médicos, é muito importante, para chegar ao diagnóstico de demência e saber qual é o estágio da doença, verificar se o paciente se lembra de fazer algo, mas não consegue realizar aquela atividade ou se ele não se lembra, mas consegue fazer. Lembrar-se de realizar as atividades da vida diária e conseguir fazê-las estariam 
no pólo da lembrança-hábito (Bergson) e da memória voluntária (Proust), o que, para esses autores, não caracterizariam a memória no sentido pleno da palavra.

Já para os médicos, enquanto lembrar-se de realizar essas atividades se refere propriamente à memória, conseguir fazê-las estaria no campo da funcionalidade, ainda que haja uma relação necessária entre as duas (só faz quem se lembra de fazer). Além disso, doentes e familiares precisam lançar mão da memória para narrar tais acontecimentos - ou não acontecimentos. Se, para Proust e Bergson, a memória involuntária, a que irrompe por meio de afetos e imagens, é a verdadeira memória, para os médicos, é a memória voluntária, aquela que se acessa por esforço intelectual e hábito - justamente os componentes tidos como comprometidos numa demência -, que é valorizada e exigida nas consultas.

\section{RECOLHER OS RASTROS}

É, sem dúvida, uma grande fraqueza para uma pessoa consistir integralmente em uma coleção de momentos, e uma grande força também; depende da memória, e nossa lembrança de um momento não está informada sobre tudo o que aconteceu desde então; esse momento que ela registrou perdura ainda, vive ainda, e com ele a pessoa cuja forma é nele delineada. (Marcel Proust. Em busca do tempo perdido)

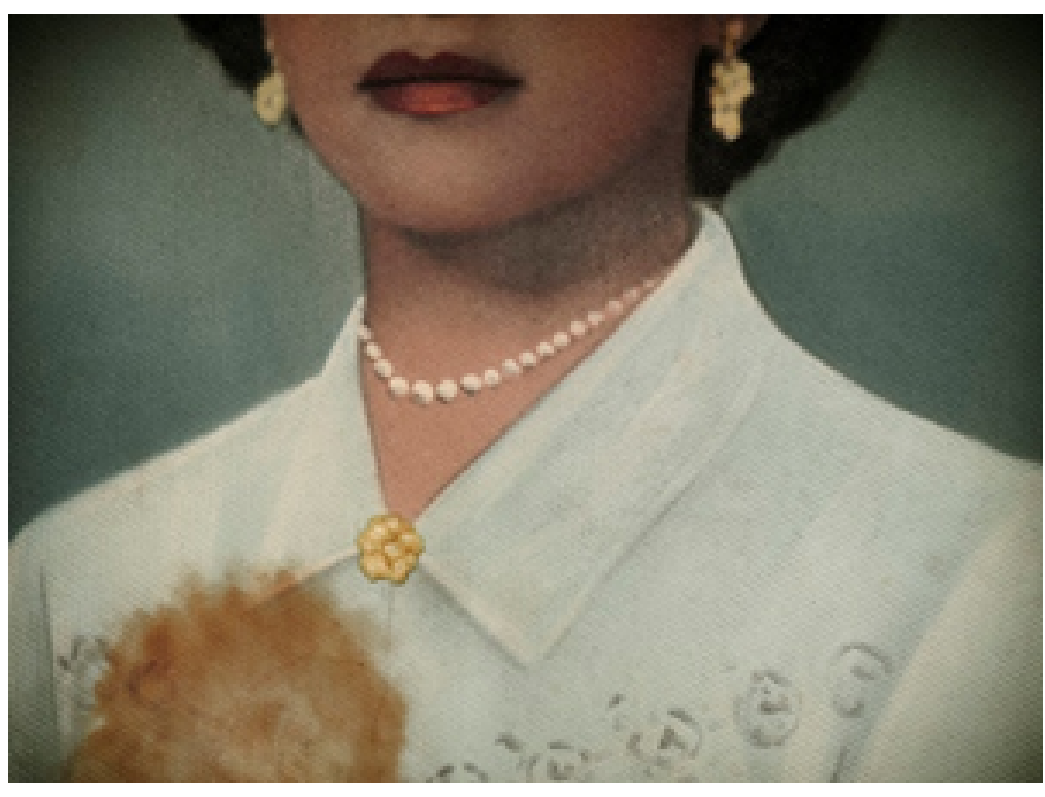

Figura 3

Ensaio fotográfico "Essa luz sobre o jardim", de Fábio Messias, que fotografou a avó com doença de Alzheimer. Para mais informações ver: http://cargocollective. com/fabiomessias/EssaLuz-Sobre-o-Jardim. de acessos ao(s) passado(s). Uma noção importante para pensar a memória, particularmente quando se lida com a sua perda, e que pode ser lida tanto numa chave metafórica quanto numa dimensão objetal/física (enquanto coisa) é a de rastro. Para Assmann (2011), a memória só se determina a partir do apagamento, da destruição, da lacuna, do esquecimento.

Passa-se dos textos aos vestígios: se antes a meta era reativar uma informação passada, com os vestígios só se pode restituir fragmentos: 
Vestígios, em comparação com os textos, possibilitam um acesso completamente diverso ao passado porque incluem as articulações não verbais de uma cultura passada - as ruínas e os elementos remanescentes, os fragmentos e os cacos-, bem como resquícios da tradição oral (Assmann, 2011: 225).

A busca por vestígios permite um novo acesso ao passado: eles dão vozes às testemunhas mudas, fornecendo outras narrativas para além das oficiais e hegemônicas. Além disso, os vestígios, ao contrário dos signos presentes na escrita, trazem a possibilidade de uma imediação não representacional, mas "de uma estampa ou impressão" (Assmann, 2011: 226). Outra vantagem é a ampliação do leque das "inscrições", como as imagens fotográficas e os objetos enquanto testemunhas do passado.

Não se trata mais de usar a memória contra o esquecimento, mas de incorporá-lo. As testemunhas deixam de ser as "falantes" mas as que foram remetidas ao silêncio e que não estão destinadas a durar. "Eles [os testemunhos] pretendem comunicar algo sobre o que a tradição geralmente cala: o dia a dia a que ninguém atenta" (Assmann, 2011: 230). Assim, chegamos ao caminho dos vestígios ao lixo ${ }^{7}$ : a contemplação do insignificante, da desordem, do imponderável; a volta do obsoleto, do esquecido, do não consciente, daquilo que foi deixado ao canto; a busca por rastros; o aprendizado das ruínas. O lixo como informação leva a registrar o efêmero e o irredutível, a voltar o nosso olhar à atenção aos detalhes, ao cotidiano; é um suporte confiável de uma memória inoficial. O lixo é o não funcional. São esses novos materiais que passam a ser valorizados e acionados no processo mnemônico. O esquecimento vem à tona com uma força jamais vista e a proposição se inverte: ter que se lembrar, em um mundo de esquecimento.

A força do esquecimento, a valorização do não funcional, dos detalhes do cotidiano, das testemunhas "mudas" são dimensões importantes para pensar nas narrativas, experiências e disputas da doença de Alzheimer, uma vez que o esquecimento que compromete a funcionalidade, as atividades do dia a dia e as falas dos doentes e dos familiares são elementos constitutivos do diagnóstico. Porém, se para Assmann o esquecimento é uma via privilegiada à memória, para os médicos ele é um obstáculo, sintoma de uma patologia.

A noção de rastro ganha um contorno mais nítido e central na obra de Ricoeur. Segundo ele, trata-se de uma noção polissêmica: "o rastro enquanto impressão material, o rastro como impressão afetiva e o rastro como impressão documental. E, a cada vez, como exterioridade" (2007: 152, nota 5). O autor também fala em rastro cerebral/cortical, tratado pelas neurociências.

O tipo de rastro afetado marcará o tipo de esquecimento acometido. Ricoeur distingue entre "esquecimento de reserva" e "esquecimento por apaga-
7 É importante salientar que a autora não está pensando em uma passagem linear-dos textos aos vestígios, dos vestígios ao lixo-mas em superposições e entrecruzamentos. 
mento de rastros". O primeiro é o esquecimento reversível, no qual o acesso aos rastros psíquicos se dá através de experiências precisas que têm como modelo o reconhecimento das imagens do passado; trata-se de um tesouro a que recorro quando me lembro de algo que ouvi, experimentei, aprendi, adquiri. As lembranças não foram definitivamente apagadas, mas apenas tornadas inacessíveis, indisponíveis, podendo se ter acesso a elas através do reconhecimento, esse "pequeno milagre da memória feliz", no qual reconheço uma imagem que me chega ao espírito, tornando o ausente, anteriormente presente, presente novamente. ${ }^{8}$

O segundo tipo é o esquecimento definitivo, com o comprometimento dos rastros neuronais/cerebrais/corticais. Ricoeur chama a atenção, assim, para a polissemia do esquecimento por meio da ideia de grau de profundidade do mesmo (uma profundidade vertical) e de seus usos (uma pragmática do esquecimento).

Ricoeur reconhece a dificuldade de se ter acesso aos rastros cerebrais, já que eles se mostram exteriormente através do conhecimento científico, o qual não pode fornecer uma prova sentida, vivida, como no caso "que nos faz dizer que vemos 'com' nossos olhos e que seguramos 'com' nossas mãos" (2007: 425). Ele percorrerá, assim, a busca das neurociências pelos rastros mnésicos, pondo para dialogar o fenomenólogo e o neurologista numa tentativa de ver o lugar que o esquecimento ocupará no quadro das disfunções da memória. "O esquecimento é realmente uma disfunção? (...) A orientação geral será a de um desvio epistemológico entre o discurso sobre o neuronal e o discurso sobre o psíquico" (2007: 426).

As neurociências correlacionam componentes mentais (ou psíquicos) e camadas corticais/cerebrais, ou seja, dependendo da parte do cérebro afetada, corresponde-se o prejuízo cognitivo afetado por aquela área (Ricoeur chama isso de correlação entre organização e função). Assim, quando a lesão se localiza na parte frontal do cérebro, há, segundo os médicos, um comprometimento maior de traços comportamentais (agressividade, desleixo com a higiene pessoal, apatia, comportamentos estranhos) e cumprimento de regras sociais (desinibição, como arrancar a roupa em público, fazer xixi em lugares públicos, assediar pessoas, uso de palavrões). Quando o hipocampo é a parte lesionada, há mais prejuízo da memória. Existe, assim, uma relação entre lesões orgânicas e sintomas clínicos ou comportamentais, apesar de nem sempre estar clara tal relação. Segundo Ricoeur, a questão, para o neurologista, é saber quando um rastro cortical é um rastro mnésico, localizando, com isso, "o esquecimento nas proximidades das disfunções das operações mnésicas, na fronteira incerta entre o normal e o patológico" (2007: 428).

Para saber se um rastro cortical é um rastro mnésico, é preciso, ainda de acordo com Ricoeur, deparar-se com a representação do tempo e, no cerne dessa
8 Em um experimento realizado pelo Nobel da Medicina Susumu Tonegawa, através de estímulo de áreas específicas do cérebro com luz azul, ratos de laboratório recuperaram experiências e memórias que pareciam esquecidas. "Os resultados fornecem algumas das primeiras evidências de que a doença de Alzheimer não destrói por completo as memórias específicas, torna-as 'apenas inacessíveis"' Disponível em http://www. revistapazes.com/nobel-damedicina-diz-que-memoriaperdida-por-alzheimerpode-ser-recuperada/, acesso em 12/08/2016. 
relação, com a dialética de presença, ausência e distância, tomando o rastro tanto como efeito presente quanto signo de sua causa ausente. A dificuldade está na materialidade/exterioridade do rastro cortical, em que tudo é positividade e presença. O neurologista, ao contrário do fenomenólogo, não busca a dialética do ausente e presente, mas a correspondência entre função e organização através de uma lógica localizacionista das lesões no cérebro. ${ }^{9}$

O esquecimento, na clínica, perde sua polissemia e aparece como disfunção/ distorção da memória - é o caso do esquecimento como apagamento de rastros. Aqui, o esquecimento é tido como inimigo da memória - esta deve lutar contra ele. "Em resumo, o esquecimento é deplorado da mesma forma que o envelhecimento ou a morte: é uma das faces do inelutável, do irremediável." (Ricoeur, 2007: 435). Para o autor, as neurociências não se debruçam sobre o paradoxo do esquecimento também como parte/condição da memória, o que explicaria o silêncio das mesmas em relação ao esquecimento comum. Até mesmo o esquecimento definitivo encontraria mais eco na poesia que na ciência, ainda mais quando associado ao envelhecimento e à morte.

Com a diferenciação entre "de reserva" e "por apagamento de rastros", Ricoeur mostra a ambiguidade do esquecimento: se, de um lado, temos a experiência da perda da memória e da morte anunciada das lembranças, de outro, há momentos em que é possível resgatá-las quando acreditávamos perdidas para sempre, podendo dizer que "esquecemos muito menos coisas do que acreditamos ou tememos" (2007: 448). É essa dupla valência da destruição e da perseverança, de um esquecer que destrói e de um que preserva, que torna possível a memória. Só nos lembramos de algo que esquecemos. Em situações normais (excluindo, por um lado, casos de doenças e, de outro, capacidades extraordinárias de memória), assim como não é possível lembrar-se de tudo, também não nos esquecemos de tudo. 10 "Em resumo, o esquecimento reveste-se de uma significação positiva na medida em que o tendo-sido prevalece sobre o não mais ser na significação vinculada à ideia do passado. $O$ tendo-sido faz do esquecimento o recurso imemorial oferecido ao trabalho da lembrança" (2007: 451). O esquecimento é tanto um paradoxo quanto um enigma.

Um paradoxo, tal como o expõe o Santo Agostinho retórico: como falar do esquecimento senão sob o signo da lembrança do esquecimento, tal como o autorizam e caucionam o retorno e o reconhecimento da "coisa" esquecida? Senão, não saberíamos que esquecemos. Um enigma, porque não sabemos, de saber fenomenológico, se o esquecimento é apenas impedimento para evocar e para encontrar o "tempo perdido", ou se resulta do inelu tável desgaste, "pelo" tempo, dos rastros que em nós deixaram, sob forma de afecções originárias, os acontecimentos supervenientes (Ricoeur, 2007: 48).
9 Para uma discussão sobre como as neurociências têm moldado nossa percepção sobre pessoa, doença e realidade, ver Rose (2001), Rose e Abi-Rached (2013), Russo e Ponciano (2002) e Azize (2010).

10 Após ouvir a queixa da esposa, que cuida do marido com doença de Alzheimer, o neurologista discordou: "não existe 'esquece tudo'!", dizendo, ao residente, que é preciso "desconfiar disso" e buscar outros elementos além da perda da memória. 
Na doença de Alzheimer, os doentes, apesar de alguns perceberem algo "errado", são, normalmente, aqueles que não sabem que esqueceram (é preciso lembrá-los do próprio esquecimento) e, por isso, muitos não se vêem como doentes ou tendo "problema de memória"11. Os rastros vão inexoravelmente sendo apagados, devendo se fazer um esforço para reunir o que resta deles, tanto para a constituição do quadro clinico quanto para o possível retardamento do mesmo. Deixar o fogão aceso, não se lembrar de onde guardou tal objeto, perder-se, não reconhecer alguém, são rastros que precisam ser recoIhidos para compor a doença, numa espécie de "atlas de memória errática" (Didi-Huberman, 2013).

Discutindo a ideia de "memória como um tesouro de sofrimentos", relacionando-a ao conceito de vestígio, Assmann analisa uma série fotográfica intitulada "Evidências", de Naomi Tereza Salmon, uma jovem israelita da terceira geração encarregada de fotografar, para fins de registro, uma série de objetos advindos do Arquivo do Holocausto em Yad Va Shem, em Jerusalém. Objetos como um pente com os dentes retorcidos, uma caneca de latão gasta, algumas cerdas sujas de barbear e um óculos quebrado tornam-se uma prática de rememoração de uma experiência em um campo de morte visto, ao mesmo tempo e de maneira ambivalente, como cena de crime, museu e memorial. Para Assmann, as fotografias de Naomi Salmon "são, assim como as lápides, testemunhas mudas do crime" (2011: 407).

Assim como as fotografias da jovem israelita, as imagens ou lembranças (ou, para usar um termo de Bergson, as lembranças-imagens) da demênciadeixar o fogão aceso, não conseguir tomar banho, esquecer onde guardou um objeto, o não reconhecimento de alguém, a confusão diante do espelho, a fala sem sentido ou repetitiva, a desinibição, o "querer ir pra casa" - são evidências, testemunhas, mas não de um crime, apesar de requerer toda uma investigação/ especulação minuciosa, quase como achando um "culpado". Nesse sentido, o doente é muitas vezes visto como responsável pela própria saúde e, portanto, pela doença, ou a família como aquela que não cuida direito, não o deixa fazer as coisas, não o estimula física e cognitivamente. As evidências, aqui, são tanto recordações quanto sintomas, em um movimento espiralar ou espectral entre presente, passado e futuro, uma "memória futura" que, como na obviação de Roy Wagner, permite ter uma visão antecipada dos eventos, sendo a causa do efeito, o efeito da causa (Dulley, 2015).

Seixas mostra como, para Proust, o tempo é uma noção complexa, havendo diversos e múltiplos tempos, sendo a descontinuidade uma marca importante, assim como "o instante único e isolado que guarda latente a possibilidade da memória". Trata-se de uma "memória fugidia, que se movimenta para frente e para trás sem obedecer a qualquer sucessão necessária" (2004: 49). A reatualiza-
11 Nas consultas, quando o residente pergunta como estão ou o que fazem ali, muitos respondem que estão bem, não estão doentes e/ou não sabem porque estão ali. Alguns ainda acionam outras causas, como "estou com tontura", "estou com dor de cabeça", "acho que é por causa do meu resfriado". 
ção da memória proustiana se dá num instante, num relâmpago, numa irrupção. Seixas continua:

É este trazer à tona que constitui o fundamento mesmo da memória, pois o passado que "retorna" de alguma forma não passou, continua a tivo e atuale, portanto, muito mais do que reencontrado, ele é retomado, recriado, reatualizado. Por isso o sentimento proustiano de que o passado outrora vivido é ressuscitado no presente: "(...) a impressão foi tão forte que o momento que eu vivia (no passado) pareceu-me ser o momento atual ${ }^{12 "}$ (Seixas, 2004: 49).

Para as pessoas que vivem um processo demencial, esse momento é o momento atual. A memória, tanto lá quanto aqui, opera uma fusão, uma superposição de tempos múltiplos e descontínuos, a qual se dá na irrupção, na duração do instante. Ao fundir instante e duração, Proust, de acordo com Seixas (2004), cria o "fora do tempo", o "atemporal", o qual só emerge ao traçar os múltiplos e descontínuos tempos que constituem a duração. O passado, "um pulsar da descontinuidade", é atualizado no presente-e, com isso, instante e duração se reconciliam.

Essa justaposição temporal, parte do próprio processo mnemônico, pode se tornar patológica em outros contextos-como no de trauma e, nas demências, em sintomas tidos como alucinatórios.

\section{ENTRE O NORMAL E O PATOLÓGICO: VERDADE CONTRAFACTUAL, TRAUMA E ALUCINAÇÃO}

Segundo Assmann (2011), a partir dos anos 1980, o nexo entre recordação e identidade ganha nova relevância. Definir-se a partir do que se lembra e do que se esquece passa a ser um fundamento importante para a constituição de identidades individuais e de grupos, sendo que a reformulação da identidade também implica uma reorganização da memória.

A memória, não mais como recipiente protetor e armazenador, fez com que o critério mais importante de credibilidade deixasse de ser a verdade para ser a autenticidade. A possibilidade de manipular ou falsear as recordações em nome do afeto delineia outro tipo de verdade - o que Assmann (2011) chamou de
12 A citação de Proust está no tomo III de Em busca do tempo perdido.

\section{Figura 4}

Ensaio fotográfico "La noche que me quieras", de Alejandro Kirchuk, que fotografou a avó com doença de Alzheimer.

Para mais informações ver: http://www.bbc.com/portuguese/ videos_e_fotos/2012/02/120214_ galeria_alzheimer_pu.shtml e http://alejandrokirchuk.com/

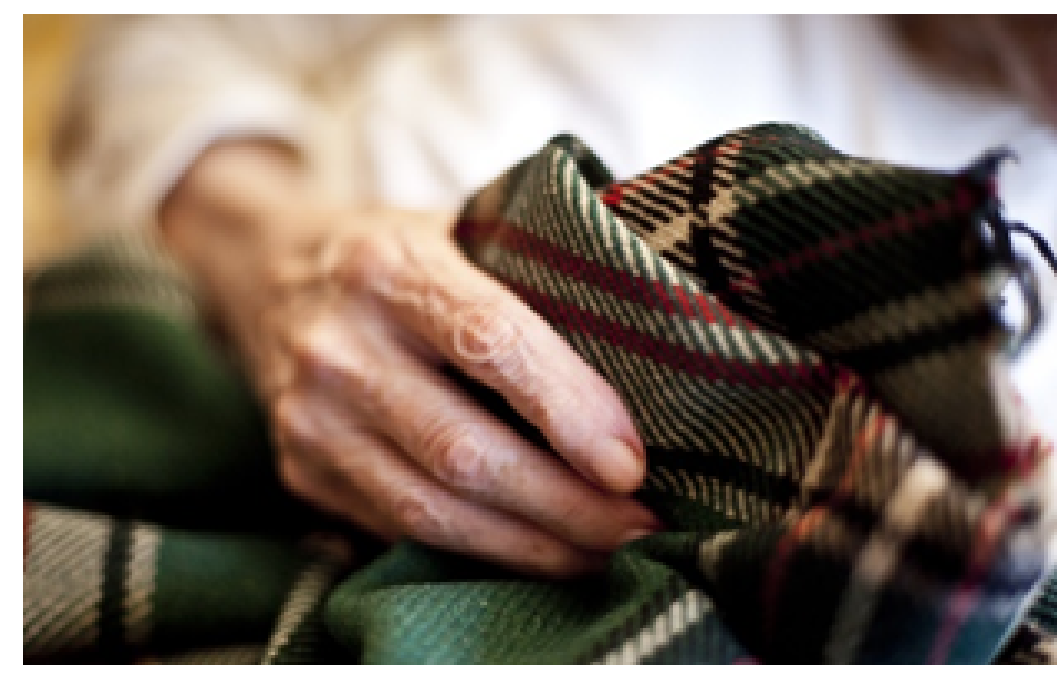


"verdade contrafactual". Ela chega a esse argumento após analisar uma série de autobiografias em que os autores, eles próprios, "duvidam" de suas lembranças, admitindo que as coisas podem não ter sido exatamente assim. Apesar de admitirem tal distorção, esses autores se apegam à memória como uma recordação afetiva e/ou uma maneira de construir/manter uma identidade. A ilusão passa a ser mais real que a própria realidade.

As recordações afetivas ganham, assim, uma qualidade irrefutável, evidente. Ao renunciá-las, não restaria outra coisa. Para Assmann, a reinterpretação não deve se equiparar necessariamente com falsificação, sendo um elemento importante para a estabilização das recordações no desenvolvimento de uma identidade pessoal.

A estabilidade de uma parte essencial de nossas recordações depende da questão acerca da possibilidade de inventar e acrescentar um tal significado ou não. Poder propor essa questão corresponde não apenas à necessidade humana, mas também à determinação humana; não é só uma questão de adaptação, mas de autodeterminação (Assmann, 2011: 276).

Assmann traz o relato de uma mulher que diz ter testemunhado a explosão de quatro chaminés em Auschwitz. Os historiadores, porém, argumentaram que o relato não era correto, já que na ocasião apenas uma chaminé foi pelos ares e não quatro. Dori Laub, o psicanalista que tinha recolhido esses relatos e estava apresentando-os na conferência em que os historiadores estavam presentes, revidou:

O que a mulher testemunhou não foi o número de chaminés voando pelos ares, mas outra coisa, mais radical e central: a realidade de um acontecimento inimaginável. Uma chaminé que foi pelos ares era igualmente inimaginável, tal como quatro. O número era menos importante que o próprio incidente. $O$ acontecimento em si mesmo era quase inconcebivel. A mulher testemunhou à sua maneira um acontecimento que destruiu um quadro coercivo de Auschwitz, precisamente onde levantes armados de judeus não ocorriam nem tinham vez. Ela testemunhou a brecha desse quadro. E tal coisa é verdade histórica (apud Assmann, 2011: 294).

Diante desse exemplo, Assmann reforça o caráter verdadeiro das recordações mesmo quando são contrárias aos fatos-ou justamente por isso. Segundo ela,

a verdade da recordação pode consistir justamente na deformação dos fatos, porque esta, assim como o exagero, registra estímulos e sentimentos que não 
ocorrem em qualquer descrição factual. Portanto, as recordações, mesmo que manifestamente falsas, são verdadeiras em outro plano. Porcerto, a verdade da atmosfera criada não pode simplesmente substituir a que é baseada em fatos. Ela não possui evidências comparáveis e incontestáveis, como a verdade histórica; é preciso haver um psicanalista ou artista para reuni-las (Assmann, 2011: 295).

Ou um antropólogo.

Se a verdade contrafactual de Assmann abre a possibilidade da memória deformar e inventar, na doença de Alzheimer existe a dúvida do cuidador-familiar se o doente se esqueceu de fazer algo ou está "mentindo", "sendo esperto". "Quando eu falo pra tomar banho, minha mãe diz que já tomou, mas não sei se é a doença, se ela esqueceu, ou se é malandragem dela, se ela está sendo esperta mentindo pra gente, isso sim!", disse uma filha, em uma reunião da ABRAz. Numa dobra deleuziana entre clínica e crítica, a memória aparece como sintoma e metáfora, causa e efeito, signo e patologia, e se desloca entre o normal e o patológico, a doença e a pessoa.

Assmann não fala em alucinação (Paul Ricoeur fala, como veremos), mas em "verdade contrafactual" cujas características como o exagero e a fidelidade aos sentimentos, em detrimento dos "fatos" ou a partir de sua deformação, parecem corresponder ao que se considera como sintomas de uma alucinação. Há, porém, uma diferença, a meu ver, fundamental: enquanto a verdade contrafactual diz respeito a sujeitos conscientes da manipulação/deformação, a alucinação se destina a sujeitos tidos como não conscientes (ou em estado de delirium), a despeito de, para eles, não se tratar de manipulação/deformação. A inventividade da verdade contrafactual é a do próprio processo mnemônico. Já a inventividade presente, como veremos, nas noções de trauma e alucinação é caracterizada em termos de "dissolução do self", que, por se deslocar de seu referente anterior, ganha um caráter extraordinário e patológico. ${ }^{13}$

Assmann não fala em alucinação, mas em trauma. Antes, porém, de falar sobre trauma, ela fala sobre corpo. Do corpo como meio, escrita e evocação da memória. A dor como acessório da recordação leva-nos à noção de uma memória corporal, em que as lembranças ficam marcadas nas cicatrizes. Aqui, o corpo é a memória. Para Assmann, a memória corporal é mais confiável que a memória mental e, enquanto esta se esvai na velhice, aquela permanece. A dor fica como uma escrita permanente no corpo - a memória como um presente constante-, contrapondo-se à recordação que requer intervalos de não presença. As cicatrizes, as feridas, a dor se tornam vestígios mnemônicos duradouros e confiáveis. Se as inscrições entalhadas na mente podem se tornar inacessíveis pelo esquecimento, as inscrições no corpo não podem ser apagadas. ${ }^{14}$ Ao longo das cenas e imagens observadas em minha pesquisa, olhar apático/perdido, cabeça baixa,
13 Na doença de Alzheimer, a expressão "dissolução do self" é usada por médicos e residentes para indicar um sintoma alucinatório, uma "perda da noção de realidade", como quando o doente não se reconhece ao se olhar no espelho. Em minha tese, problematizo tal expressão ao mostrar como ela se conecta a uma determinada noção de pessoa e a uma interpretação orgânica sobre a doença. Ao trazer novas interpretações possíveis-bem como os relatos dos próprios doentes -, é possível dissolver e/ou potencializar a dissolução.

14 Para uma discussão sobre inscrições corporais em rituais e suas relações com memória e identidade, ver Clastres (2003). 
andar devagar, tremor/rigidez, um tipo de corte do cabelo (curto) parecem ser as marcas corporais que não se apagam, as pistas de uma corporalidade "demente".

O corpo, porém, assume o lugar da metamorfose. Se ele pode dar sinais da patologia, ele também pode ser acionado de maneira reversa para criar uma noção de memória-e de doença e pessoa - à revelia do discurso médico. Em uma reunião da $A B R A z$, uma filha, que cuida da mãe com a doença, disse: "às vezes meu irmão fala 'a mãe ficou brava'. Deixa ela ficar brava, deixa ela se expressar, deixa ela ser ela! Não é a doença, é o poder que ela ainda tem de ser ela!". Para Franzen (2012), o pai, com doença de Alzheimer, permaneceu se expressando até o fim, mesmo quando as palavras não mais saíam. "Impressiona-me, acima de tudo, a aparente persistência de sua vontade" (ênfase original, 2012: 14). A recusa em comer, os olhares, os gestos poderiam, assim, evidenciar a intenção, a vontade, o desejo do pai em não mais querer viver daquele modo ou, ao menos, como ele via e sentia a vida que vinha levando, bem como as atitudes e comportamentos dos outros ao seu redor. Não comer, aqui, além de ser um possível sintoma ou decorrência da doença, pode ser a persistência da vontade do doente, assim como o não tomar banho pode ser "manipulação", "mentira", "esperteza".

Voltando à Assmann (2011), depois de falar de corpo, a autora aciona a noção de trauma como central para a evocação das lembranças. Para isso, faz uso, novamente, de autobiografias. São narrativas marcadas, principalmente, por guerras e pelos campos de concentração, nas quais haveria a desintegração do selfe uma despedida do léxico de conceitos que o caracteriza, tais como escoIha, vontade, poder de reflexão, asseguração de expectativas, caracterizando uma "memória não heroica". O trauma impediria a conversão da experiência em símbolos, a tradução em uma linguagem e a construção de uma identidade possível ${ }^{15}$. No entanto, e aqui está a ambivalência do trauma, a experiência traumática requer justamente as palavras. As palavras, ao mesmo tempo comuns e triviais, tornam o trauma uma experiência singular, única. Se existe a necessidade de narrar, também há a insuficiência, os limites dessa narração. ${ }^{16}$

Para Assmann, a autobiografia de Ruth Krügler, uma sobrevivente dos campos de concentração, expõe o paradoxo do trauma ao se defender contra a estreita vinculação de seu nome a Auschwitz. Segundo a autora, o trauma, por mais marcante que seja, não se imprime em alguém como uma origem o faz. Assim, ela argumenta que o trauma, ao mesmo tempo em que se constitui como uma parte inalienável do indivíduo, não é assimilável na estrutura identitária da pessoa, sendo um corpo estranho; é, ao mesmo tempo, interno e externo, presente e ausente.

Os elementos negativos do trauma - não espacialidade, intemporalidade, ausência de signos - intensificam-se no que Assmann chamou de "forma mística da morte em vida"17, que acaba por se tornar um símbolo da resistência contra
15 Gagnebin (2004) vai mostrar que Walter Benjamin, inspirado em Baudelaire, e Freud, a partir de casos clínicos, também refletem sobre a experiência do choque - ou do trauma - e a impossibilidade de uma narrativa tradicional que a assimile, uma vez que separa o sujeito do acesso ao simbólico, à linguagem.

16 Sobre testemunhos do trauma, ver SeligmannSilva (2003).

17 A imagem de uma "morte em vida" se faz presente nas narrativas, principalmente dos familiares, sobre a condição extremamente debilitante (apatia, falta de vontade, dependência, perda da coordenação motora, afasia) e o longo processo através do qual a doença pode se arrastar "Sou viúva de um marido vivo", diz uma esposa sobre o marido, que tem diagnóstico de doença de Alzheimer. 
qualquer forma de atribuição de sentido, "símbolo de um 'resto' indissolúvel" (2011: 281). O filósofo francês Jean-François Lyotard propõe pensar no trauma a partir da "ação paradoxal de uma doença sob prescrição" (apud Assmann, 2011: 281), ou seja, o trauma como estabilizador adequado para a recordação, no caso, do holocausto. O conceito de trauma se torna, assim, metafórico, indicando uma crise geral da representação.

A doença de Alzheimer também sinaliza uma crise geral da representação: como mistério diagnóstico, um "embrolho" difícil de desatar, ${ }^{18}$ que desestabiliza o paradigma médico, com uma definição escorregadia e nebulosa que abarca uma multiplicidade de experiências. ${ }^{19}$ A noção de trauma como metáfora, com os seus elementos de desorientação espacial e temporal, ausência de sentido, "desintegração do self", também é eficaz para pensar nas narrativas e experiências da doença de Alzheimer, uma vez que tais elementos são recorrentes e constitutivos das mesmas. Além disso, o paradoxo do trauma - ser, ao mesmo tempo, uma parte inalienável e um corpo estranho - se aproxima da ambivalência na forma com que familiares e profissionais da saúde lidam com o doente-ora como pessoa que age (quando destacam as manipulações conscientes de sua condição ou quando realizam atividades que reforçariam uma subjetividade), ora como "tomado" pela doença, a doença como agente/sujeito (quando dizem não ser mais a pessoa agindo, mas a doença - frases como "isso é da doença, não leve para o pessoal; não é ele, é a doença"). ${ }^{20}$

A maleabilidade das recordações individuais faz com que, para Assmann, possamos estimar tanto seu bloqueio quanto o seu excesso. Tanto o afeto quanto o trauma agem nessas recordações como acessórios poderosos para atestar a autenticidade e veracidade das mesmas. A ambivalência da memória está justamente na constatação de que a interpretação e transformação do passado não excluem a conclusividade, a indisponibilidade, a impressão e as marcas desse mesmo passado. A memória, portanto, não é nem apenas estabilidade, nem só versatilidade, mas um jogo, uma dança ou uma luta entre essas duas dimensões.

Em um tom mais filosófico, em que a preocupação com o acesso à verdade e ao real é central e, talvez por isso, diferentemente de Assmann, o tema da alucinação se torna explícito no trabalho de Ricoeur (2007). O autor critica a associação entre memória e imaginação: enquanto a memória buscaria uma fidelidade ao real e anterior (essa seria sua ambição e pretensão), a imaginação estaria no âmbito do irreal, do fictício, do possível. Nesse sentido-e Ricoeur admite isso-, a memória pode ser pouco confiável, mas apenas porque ela se mostra como o único recurso de que dispomos para falar sobre as coisas passadas, ao passo que tal censura não cabe à imaginação, a qual, para o filósofo, só entra na memória como uma armadilha, um deslize, uma peça (no sentido de "pregar uma peça") quando temos a alucinação.
18 Numa frase de um psiquiatra, ao comentar as novas pesquisas sobre diagnóstico precoce: "o biomarcador é importante, mas achar que ele vai desatar, acabar com o embrolho..."

19 A crise geral da representação também pode ser vista na perda gradual da linguagem verbal ou no "problema com as palavras", tal como Kris, autora do blog "Creating memories", descreve. Em minha tese, mostro como a linguagem, tal como a memória, não simplesmente - ou apenas - se perde, mas se abre, (re)inventa, torce, delira. Também trago obras de artes de dois artistas diagnosticados com doença de Alzheimer (William Utermohlen e Carolus Horn), as quais, com o decorrer da doença, tornamse cada vez mais abstratas.

20 A noção de trauma também se faz presente em algumas narrativas dos familiares que associam o início da doença a um episódio traumático ou de grande estresse vivido pelo doente. 
A alucinação é a "cilada do imaginário". A direção para o polo alucinatório é vista por Ricoeur como uma "virada", "reviravolta" da problemática da memória, sendo essa "memória assombrada" "alvo comum das críticas dos racionalistas da memória" (2007: 69). Ao anular a ausência e a distância, ao fazer aparecer o objeto desejado/pensado, o encantamento - vale dizer, a alucinação-mistura memória e imaginação (a lembrança como imagem), tornando presente o ausente. "O 'não estar ali' do objeto imaginado é recoberto pela quase-presença induzida pela operação mágica" (2007: 69).

Apesar de muitas das situações de alucinação envolverem a percepção e vivência de uma experiência temporal, tais fenômenos ocupam um lugar ambíguo em relação ao processo mnemônico: ora como parte dele, ora como estranhos ou contrários a ele. A separação entre memória e imagem/imaginação, presente em Paul Ricoeur, abre a possibilidade para se pensar a alucinação como uma cilada do imaginário à memória. Já os autores que fazem uma junção entre memória e imagem, como Aleida Assmann, debruçam-se sobre as metáforas e fantasias/invenções decorrentes de uma manipulação consciente do real (como nas noções de verdade contrafactual e trauma) - ou, ao menos, ainda que a manipulação não seja consciente, o sujeito que manipula o é.

Quando memória e imaginação se combinam, parece não haver lugar para a alucinação, a qual é vivida num sentido literal: não se trata de uma metáfora, mas da própria realidade - a pessoa, de fato, ouve e/ou vê aquilo que diz/acredita. Aqui, além de não haver consciência do caráter manipulado/alterado dos "fatos", o sujeito também é visto como não consciente (demente). A alucinação é uma categoria acusatória; só tem esse caráter pelos olhos de outrem (familiar, médico).

Se os médicos tentam separar memória e alucinação, algumas situações parecem embaralhá-las. Quando Jussara disse que comeu bolo de chocolate com os pais (que já faleceram), trata-se de uma lembrança ou uma visão, uma memória ou um delírio?

\section{QUANDO A MEMÓRIA ALUCINA}

Levantei de madrugada e fui bem devagar ver o que estava acontecendo, ele estava dentro do banheiro falando com o espelho (não sabia se ria ou chorava), fui ficando atrás dele e quando minha imagem foi refletida no espel ho, ele ficou olhando para o espelho e perguntou: quem é essa mulher do seu lado? E eu, bem calma, respondi: sou a filha dele, ele se virou, olhou para mim, acho que percebeu a voz bem atrás dele, e me perguntou quem eu era, respondi, e ele me disse: você é a dona da casa e me apresentou ao cara (ele) do espel ho, fiquei chocada com tudo aquilo, olhei para o espelho, falei que ele tinha que trabalhar no dia seguinte e que precisava dormir, demos tchau ao suposto 


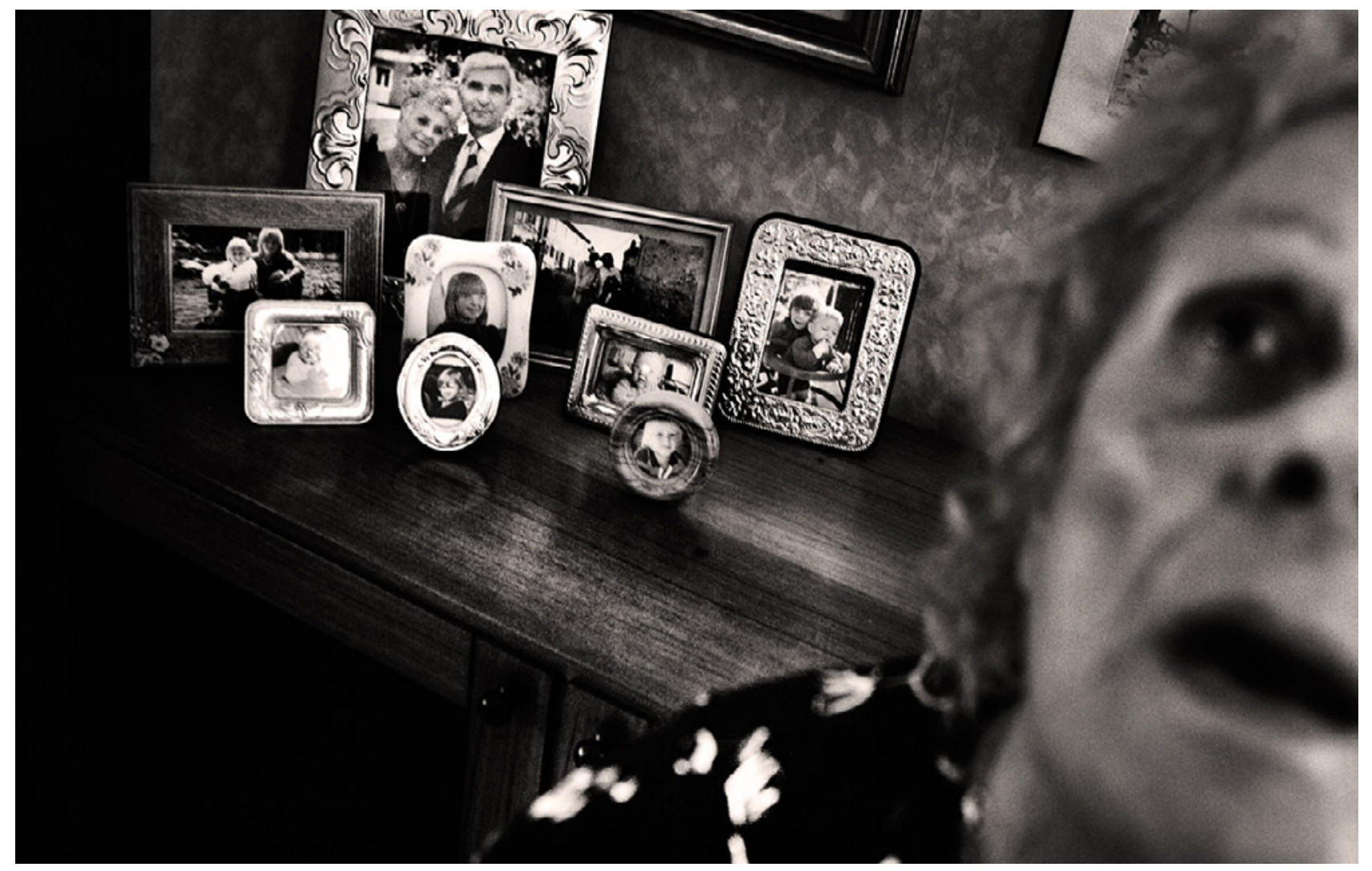

amigo. Estou estarrecida com essa doença, como ela transform a uma pessoa, sempre fui muito próxima do meu pai, sempre tive muito medo de perdê-lo, mas minha sensação é de que meu pai já não existe mais, apenas outra pessoa no seu corpo, é muito estranho tudo isso.

(Na página do Facebook "Portadores de Alzheimer e cuidadores").

A queixa de "querer ir pra casa" pode estar relacionada ao não reconhecimento dos próprios parentes e, na fase mais avançada da doença, ao não reconhecimento de si. O passado como presente faz com que algumas pessoas vivam outro tempo - o tempo em que os filhos eram jovens, os pais eram vivos; 0 tempo em que eles próprios eram mais jovens, trabalhavam. É comum se referir a esse "tempo outro" como se fosse - e, para eles, é - o tempo agora, presente. Assim, dizem que trabalham - quando já não mais o fazem -, que os filhos são crianças - quando já são adultos -, que os pais estão vivos - quando já não mais estão. Por isso, quando um homem de cabelos brancos se refere a eles como pai ou mãe, isso causa estranhamento e uma possível reação é negar que aquele é o seu filho. "Meu irmão já tem cabelo branco. Aí minha mãe olha pra ele e fala: não, não é meu filho não. Eu não tenho filho de cabelo branco!", contou uma filha que cuida da mãe, numa reunião da ABRAz. O mesmo acontece quando, ao se olhar no espelho e ver alguém mais velho do que se supõe ser, considera-se que o reflexo é outra pessoa.

\section{Figura 5}

Ensaio fotográfico "Mirella”, de Fausto Podavini, que fotografou um casal de idosos (o marido com a doença de Alzheimer e a esposa como cuidadora) Para mais informações ver: http://www.hypeness.com. br/2013/05/projeto-fotograficotocante-mostra-o-dia-a-diade-uma-esposa-cuidandodo-marido-com-alzheimer/e http://www.faustopodavini.eu/ 


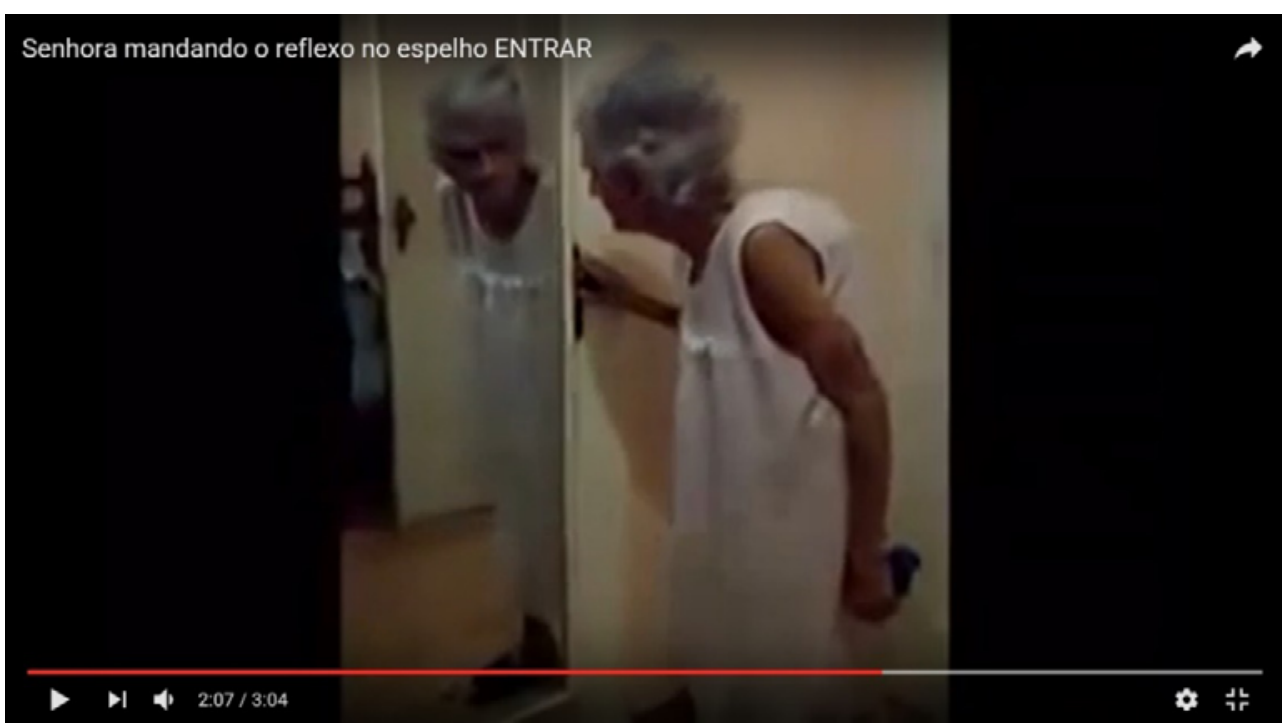

Figura 6

Em um vídeo que circulou numa página de cuidadores no Facebook, uma senhora, olhando para o espelho, convida a outra pessoa para entrar no quarto onde ela estava. "Entra!", dizia, dando espaço para a pessoa passar. Vendo que a pessoa não entrava e continuava ali, a senhora ficou exaltada, brava. "Entra!", gritava, cada vez mais. O episódio foi filmado pelo filho, entre risos e assombros. ${ }^{21}$

Jimmie G., de 49 anos, paciente do neuropsiquiatra Oliver Sacks, assombrou-se com a imagem que viu no espelho. O médico assim contou a conversa que teve com ele:

"Evocê, Jimmie, quantos anos tem?"

De um jeito esquisito, incerto, ele hesitou por um momento, como se estivesse calculando.

"Bem, acho que tenho dezenove, doutor. Vou fazer vinte no próximo aniversário". Olhando o homem grisalho à minha frente, tive um impulso pelo qual nunca me perdoei. Foi, ou teria sido, o cúmulo da crueldade se houvesse qualquer possibilidade de Jimmie lembrar-se do que sucedeu.

"Tome", eu disse, e mostrei a ele um espel ho. "Olhe-se no espel ho e me diga o que vê. É um rapaz de dezenove anos que está olhando no espel ho?"

Ele empalideceu subitamente e agarrou os braços da poltrona. "Meu Deus!", murmurou. "Meu Deus, o que está acontecendo? O que houve comigo? Será um pesadelo? Estou louco? Isto é uma brincadeira" - e se descontrolou, entrou em pânico (Sacks, 1997: 40).

Viver nesse "tempo outro" - o passado presentificado-, o que leva a um "mundo outro" - o mundo às avessas da demência - é tão significativo nas demências que um laboratório farmacêutico usou esse tema, em 2010, para uma campanha de lançamento de um remédio para postergar a perda da memória, indicado

21 Disponível em https://www.youtube.com/ watch?v=66gqD_Qm-cc, acesso em 21/10/2015. 


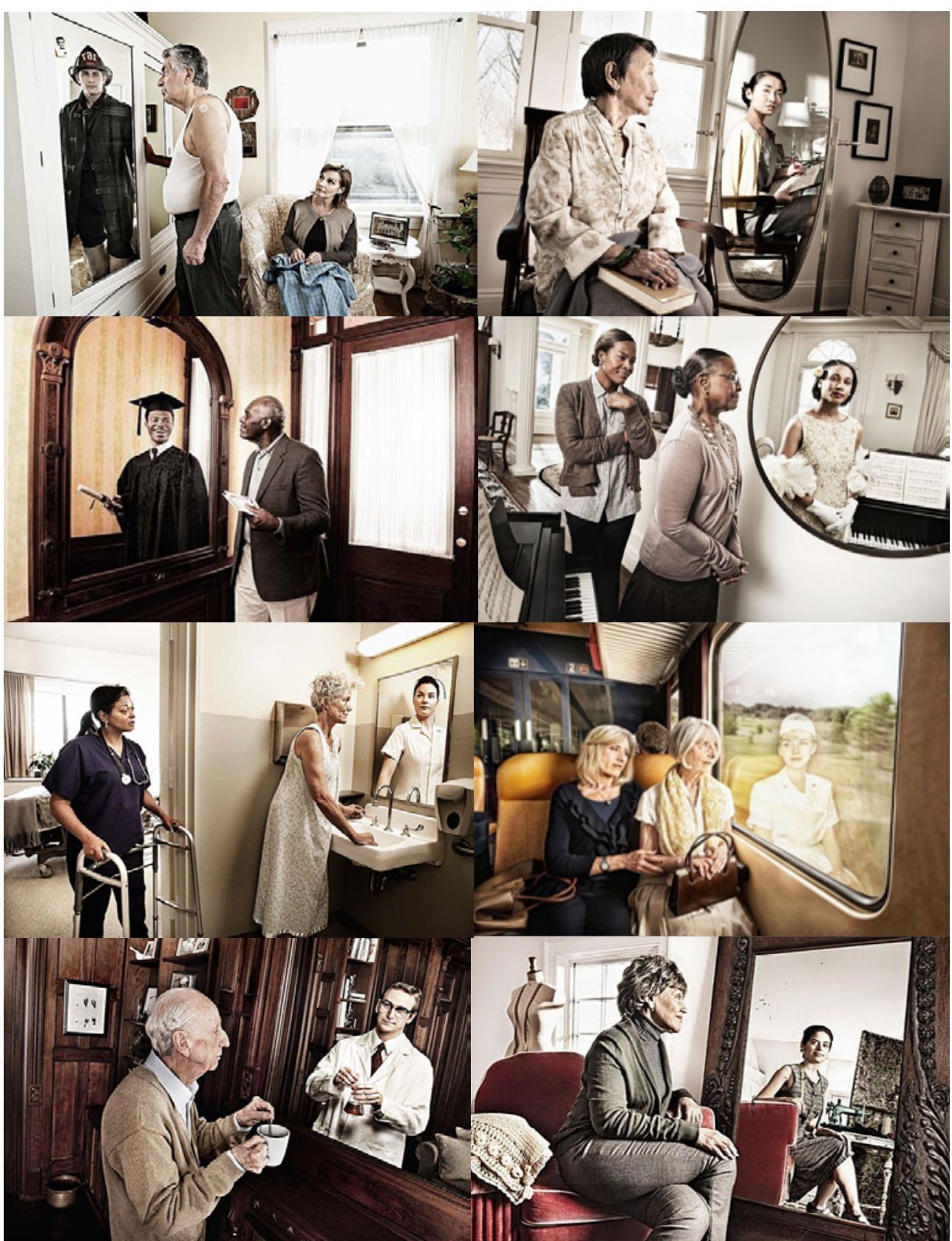

Figura 7

"Reflections", por Tom Hussey. As fotografias podem ser vistas no Coogle Imagens. Acesso em 18/03/2015.

para as fases leve e moderada da doença de Alzheimer. Nas fotografias feitas pelo norte-americano Tom Hussey, num ensaio que teve como título "Reflections", o espelho revela a incongruência e o distanciamento entre aquele que vê e o reflexo do que é visto. Assim, os velhos se vêem jovens, em outros trajes, afazeres e contextos. Eles vêem outro tempo - o tempo da juventude, do passado, da profissão, da saúde.

O assombro diante do espelho se insere "numa outra temporalidade de experiência: num deslocamento" (ênfase original, Didi-Huberman, 2013: 45). 0 filósofo e historiador Ceorges Didi-Huberman, seguindo as linhas do historiador da arte Aby Warburg, resgata a noção de sobrevivência como "um outro tempo", 
no qual há o paradoxo de que "as coisas mais antigas às vezes vêm depois das coisas menos antigas" (ênfase original, 2013: 69). Nesse nó temporal, "o presente se tece de múltiplos passados", numa "mistura de coisas passadas e coisas presentes" (2013: 46/45). A via privilegiada de acesso aos tempos vertiginosos das sobrevivências é através do sintoma, ou seja, do absurdo, do lapso, da doença, da loucura, do menos apto - por isso a noção de sobrevivência, aqui, não tem a ver com um viés evolucionista, mas com emaranhado, sobreposição temporal. A sobrevivência é o rastro, é abrir o tempo para ver fantasmas, em sua impureza e indeterminação - "o depois quase se liberta do antes, quando se une ao 'antes do antes' fantasmático que sobrevive..." (2013: 69).

Nesse tempo impuro, nesse jogo tenso de latências, lapsos, vertigens - ou, em outra metáfora usada por Didi-Huberman $(2007,2015)$, no movimento ziguezagueante e fugaz de uma borboleta que passa, aparece para depois desaparecer-, a memória, como um sismógrafo, capta os movimentos subterrâneos, invisíveis, imperceptíveis que, quando vem à tona, provocam terremotos. Como tremores subterrâneos, as ondas mnêmicas se dão por saltos descontínuossobem e descem e não sabemos quando vão aparecer e se vão nos derrubar -, a parições inesperadas - como, em minha pesquisa, o "querer ir pra casa", o ver-se no espelho e não se ver-, e ocasionam choques, rupturas, abalos, fissuras, quando momentos invisíveis, submersos, manifestam-se subitamente, como espasmos, assombros. A memória se torna o intervalo entre o que aconteceu e o que foi descoberto/veio à tona, entre a aparição e a desaparição.

Ainda de acordo com Didi-Huberman (2013), não se trata de uma reconciliação entre presente e passado, mas de uma experiência de um passado que, súbito, vem cindir o presente, divorciá-lo de sua genealogia. Nesse sentido, o "querer ir pra casa", em minha pesquisa, não é a busca de uma origem, mas revela uma sobreposição temporal, um momento-sintoma, uma aparição inesperada, uma memória que se torna ato e se expressa no corpo - viver aquilo no presente e não lembrá-lo como passado. O símbolo-casa-é incorporado numa linguagem motora - perambulação, fazer a mala, querer sair de casa.

O trabalho da memória é, assim, para Didi-Huberman, o de emaranhar e desemaranhar os fios do novelo móvel do tempo, tal como a metáfora da coordenadora da ABRAz ao introduzir a doença para os cuidadores-familiares: "é como se os fios fossem se soltando aos poucos". A memória é um "quebra-cabeça anacrônico" (Didi-Huberman, 2013: 401), um ato que recolhe os fragmentos, os rastros, os restos que vão ficando desse movimento, dessa intricação temporal. ${ }^{22}$

A proposta de Warburg, recuperada por Didi-Huberman, é a de uma sintomatologia do tempo: o sintoma é visto como uma dobra entre dentro e fora, exterior e interior, como “irrupção (surgimento do Agora) e retorno (surgimento do
22 Severi (2007) toma a memória como uma quimera, uma imagem que se constitui por fragmentos e tempos heterogêneos através de um processo de percepção $\mathrm{e}$ projeção, ordem e saliência, no qual se mobilizam, através de suas partes visíveis (uma lembrança, por exemplo) os componentes invisíveis, fantásticos, alucinatórios - como preencher os espaços em branco de uma imagem a partir das pistas que ela fornece, num trabalho que é tanto um ato de olhar quanto de imaginar/ pensar/inventar. Preencher os espaços em branco através de recordações, pistas e rastros de cenas cotidianas é o que fazem médicos, cuidadoresfamiliares e doentes na composição do diagnóstico da doença de Alzheimer. 
Outrora)", uma "concomitância inesperada de um contratempo [descontinuidade, esquecimento] e uma repetição [continuidade, lembrança]" (ênfases originais, Didi-Huberman, 2013: 149). Não se trata, portanto, do sintoma tal como para a medicina, como categoria clínica, com critério definido e quadro regular para ver continuidades e semelhanças; o sintoma como determinação (diagnóstico). Para Warburg, o sintoma é uma categoria crítica, que faz explodir/abrir o quadro regular e os critérios; o sintoma, para ele, é o não portador de sentido, é a sobredeterminação (paradoxo). Assim como a memória perde a sua polissemia na clínica - e o que foge ao critério de um bom funcionamento se torna patológico -, o sintoma também perde o seu caráter de símbolo. A doença de Alzheimer, porém, parece tornar tudo mais complicado, embaralhado, incerto também para a medicina: a doença desafia os critérios científicos, faz o diagnóstico se arrastar por anos, às vezes de maneira a nunca se concluir, e não dissolve as incertezas que a rondam.

A diferença temporal - esse "outro tempo" ou a coexistência do presente como passado e futuro - aparece como estranheza, deslocamento, desorientação, como nos relatos e nas cenas da doença de Alzheimer vistos ao longo da minha pesquisa. Para Didi-Huberman, as situações incompreensíveis têm os "poderes de uma lembrança em suspenso" (2013: 273), o "poder de intensificar um gesto presente, destinando-o ao tempo fantasmático das sobrevivências. É a estranheza que, no choque anacrônico do Agora (a serva) com o Outrora (a Vitória), abre para o estilo seu próprio futuro, sua capacidade de mudar e de se reformular inteiramente..." (2013: 216).

Nesse devir outro, a capacidade de mudar e de se reformular pode tanto ter uma dimensão positiva - dobrar a linha do fora, para usar uma expressão deleuziana, e fazer da doença um modo de subjetivação - quanto negativa -cruzar a linha da loucura, como fala Joe ${ }^{23} \mathrm{e}$ alguns cuidadores-familiares, e perder-se a noção de quem se é (como na expressão médica "dissolução do self"). Se, como vimos, a memória se dá por fragmentos, rastros, restos, a constituição de um "self" - ou de uma noção de pessoa-também se dá de maneira fragmentária, descontínua, seletiva, inventiva. ${ }^{24}$

Para Didi-Huberman, quando o sismógrafo-vale dizer, a memória-quebra, afunda, desmorona, a mistura de temporalidades acontece no mesmo plano de inscrição e aí temos a loucura, as crises, os lapsos, "a experiência de beirar abismos" (2013: 126). É quando a memória alucina - o passado aparece como alucinação -, vê/ouve fantasmas, abre-se para o tempo do sintoma, do absurdo, do incompreensível. Na doença de Alzheimer, a não cronologia temporal pode não ser "apenas" memória - a vivência de um "tempo outro" -, mas também alucinação-a vivência de um "mundo outro", numa sobreposição entre fatos e delírios, lembranças e visões.

23 Joe, diagnosticado com doença de Alzheimer e demência frontotemporal, é autor do blog "Living with Alzheimer's".

24 Se, para o pensamento científico ou "ocidental", existe uma relação entre memória e pessoa (ou "self"), é preciso levar em conta que essa relação é múltipla, descontínua e em constante movimento. Como discuto em minha tese, a centralidade da memória na doença de Alzheimer e/ou a perda da memória como sintoma patológico indicam determinada noção de pessoa e interpretação da doença, em que o cérebro assume um lugar privilegiado. Ao olhar para as imagens e as pessoas em processo demencial, além de fazer um diálogo com o xamanismo, mostro como é possível trazer outras referências para pensar outras noções e mundos possíveis na experiência com a doença. 
A queixa do cuidador-familiar da pessoa em processo demencial "querer ir pra casa" revela como a memória se faz na sobreposição entre tempo e espaço, invenção e alucinação, lembrança e esquecimento, em um deslocamento que é tanto físico quanto metafórico. Casa, aqui, como o espelho, atua tanto como coisa quanto como metáfora para ressignificar a experiência mnemônica vivida pelos doentes como realidade e pelos familiares como alteridade. São imagens-objetos que embaralham, tensionam ou tornam ambígua a relação entre função referencial e função estética/poética, e tanto descrevem quanto expressam cenas vividas na experiência com a doença. Se, muitas vezes, o referente do passado é real (os pais, a casa da infância, o trabalho), o uso deles no presente se dá de uma maneira inventiva, surreal.

A memória, assim, se torna tanto conceito quanto metáfora da doença de Alzheimer. Se casa e espelho revelam as sobreposições do processo mnemônico, o dente de leão, planta formada por vários filamentos, os quais, quando assoprados ou em contato com o vento, soltam-se e saem voando, foi muito usado em materiais informativos pela $A B R A z$ para se falar do processo contínuo e irreversível da doença, principalmente no que se refere à perda da memória e a importância de se preservá-la - não só o que resta dela nos doentes, mas também a memória das pessoas saudáveis; tanto como forma de prevenção, quanto como meio de não se esquecer da doença. ${ }^{25}$ Com seus fios entrelaçados, vulneráveis e complexos, que ora se separam, ora se juntam, o dente de leão - e, portanto, a memória - indica o próprio emaranhado do tema: a doença de Alzheimer, marcada pela vulnerabilidade, dissolução e confusão, é, ela própria, um emaranhado de relações, saberes e práticas, um misto entre orgânico e inorgânico, demência e lucidez, numa transversalidade que não se sabe onde começa um e termina ver nas imagens abaixo, cada semente do dente de leão lembra o formato de um neurônio e, quando agrupadas, parece a representação de uma rede neural.

\section{Figura 7}

Figuras encontradas em panfleto da Associação Brasileira de Alzheimer (ABRAz): dente de leão como meio para falar da memória
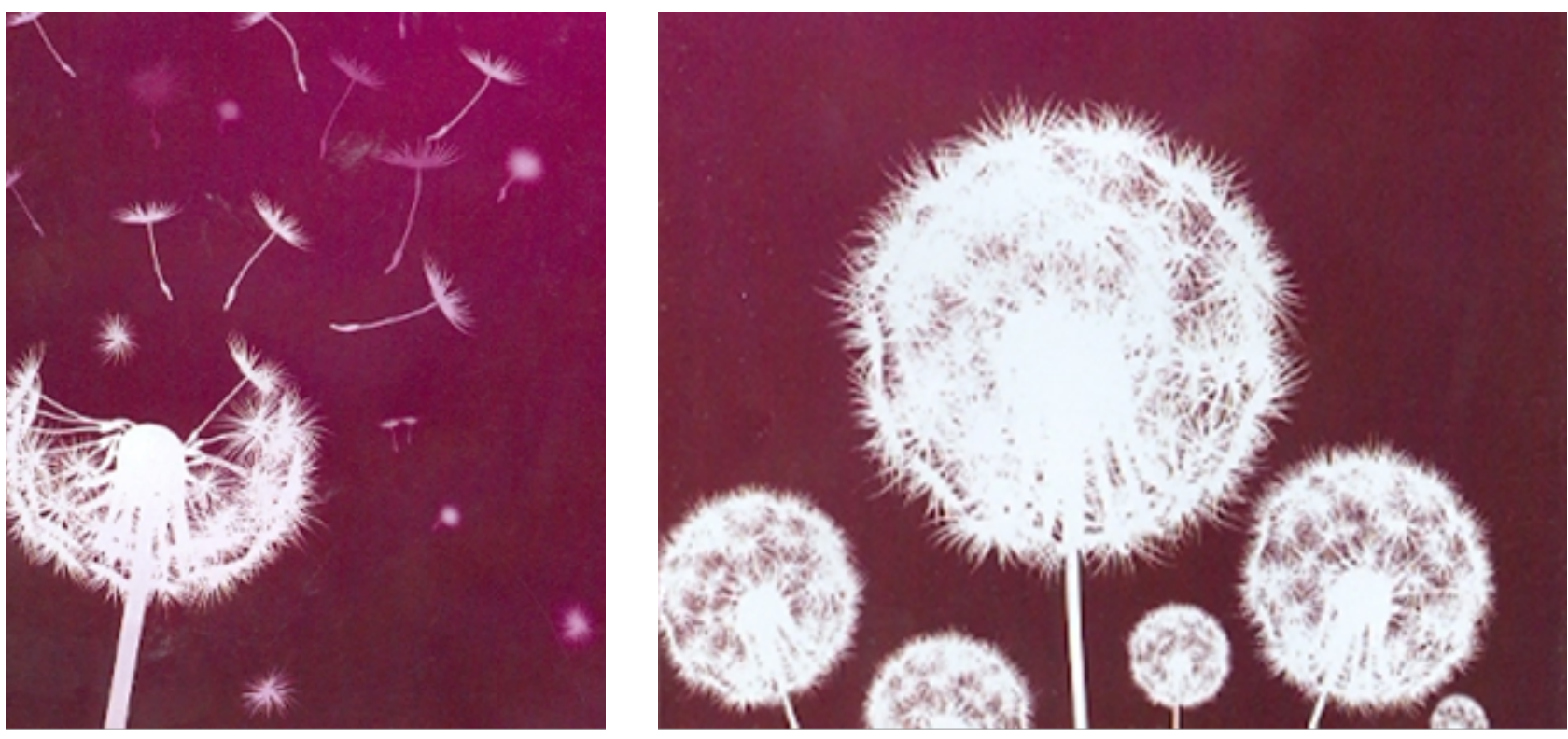

Rev. antropol. (São Paulo, Online) | v. 60 n. 2: 532-561 | USP, 2017 
outro. Como as sementes que vão se soltando e, ao caírem, germinam, os fios da doença também vão se soltando, deixando rastros, pistas, num movimento, tal como no processo mnemônico, de dissolver e compor, desmanchar e criar, conter e transbordar.

Se a doença de Alzheimer já foi associada aos tempos modernos em crise com a memória, ao empobrecimento da narrativa e experiência e à ameaça aos valores neoliberais (Robbins, 2008; Burke, 2015; Wearing, 2015; Coldman, 2015), é preciso levar em conta que, em vez da memória apenas ou simplesmente se perder, ela se transforma e transborda para outras dimensões, como os gestos, os lapsos, as aparições, os vestígios. Como um "narrador sucateiro", essa abertura da memória leva-nos a recolher as sobras que ficam nas margens dos discursos oficiais e hegemônicos, como o biomédico, possibilitando ver o que normalmente não se vê numa doença como essa. Um comentário, uma piada, uma mão que segura um cobertor, um ol ho que brilha, uma linguagem que se inventa, os pingos d'água depois do banho, a borra de café na xícara, uma foto guardada, um quadro, um passeio, uma queixa, um riso, um choro, uma recusa, um desejo são os lampejos dessa noite escura, a dança entre lembrança e esquecimento, o movimento serpeante do processo mnemônico.

Não se trata de negar o terror e a materialidade da doença, mas de ver, em meio a névoa, a potencialidade da dissolução, do borrão, do lapso, do desmoronamento. O sintoma - como a perda da memória e alucinação-, além de indicar uma patologia, também revela uma experiência, uma subjetividade. E, assim, a "doença do esquecimento", a doença cujos "fios vão se soltando aos poucos", torna-se um modo de vida, um mundo possível, uma linha de fuga, e (re)inventa a memória, leva-a a delirar.

Daniela Feriani é Doutora em Antropologia na Universidade Estadual de Campinas e pesquisadora do Laboratório Antropológico de Grafia e Imagem (La'grima / Unicamp).

\section{REFERÊNCIAS BIBLIOGRÁFICAS}

ASSMANN, Aleida

2011 Espaços da recordação: formas e transformações da memória cultural. Campinas, SP, Editora da Unicamp. 


\section{AZIZE, Rogério Lopes}

2010 A nova ordem cerebral: a concepção de "pessoa" na difusão neurocientífica. Rio de Janeiro, tese de doutorado, UFR].

BENJAMIN, Walter

1987 "Experiência e pobreza". In Walter Benjamin-Obras escolhidas. Vol. 1.

Magia e técnica, arte e política: ensaios sobre literatura e história da cultura.

Prefácio de Jeanne Marie Gagnebin. São Paulo, Brasiliense, pp. 114-119.

1994 "O Narrador: considerações sobre a obra de Nikolai Leskov".

In Magia e técnica, arte e política: ensaios sobre literatura e

história da cultura. São Paulo, Brasiliense, pp. 197-221.

\section{BERCSON, Henri}

1999 Matéria e memória: ensaio sobre a relação do corpo com o espírito. São Paulo, Martins Fontes.

BURKE, Lucy

2015 "The locus of our dis-ease: Narratives of family life in the age of Alzheimer's". In SWINNEN, Aagje e SCHWEDA, Mark (orgs.). Popularizing Dementia: Public Expressions and Representations of Forgetfulness. Aging Studies, vol.6. Alemannha, Transcript Verlag, Bielefeld, pp. 23-42.

CLASTRES, Pierre

2003 "Da tortura nas sociedades primitivas". In A sociedade contra o Estado. São Paulo, Cosac \& Naify.

DIDI-HUBERMAN, Georges

2007 La imagen mariposa. Trad. Juan José Lahuerta. Barcelona, Mudito \& Co.

2013 A imagem sobrevivente: história da arte e tempo dos fantasmas segundo Aby Warburg. Rio de Janeiro, Contraponto.

2015 Falenas - Ensaios sobre a aparição 2. Lisboa, KKYM.

DULLEY, Iracema

2015 Os nomes dos outros - etnografia e diferença em Roy Wagner. São Paulo, Humanitas/Fapesp.

FERIANI, Daniela

2017 "Pistas de um cotidiano assombrado: a saga do diagnóstico na doença de Alzheimer". Ponto Urbe (online), n. 20. 
FRANZEN, ].

2012 "O cérebro do meu pai". Revista Piauí. Disponível em: http://revistapiaui. estadao.com.br/edicao-69/memorias-de-familia/o-cerebro-do-meu-pai.

GACNEBIN, Jeanne Marie

2004 "Memória, história, testemunho". In BRESCIANI, Stella e NAXARA, Márcia (orgs). Memória e (res)sentimento: indagações sobre uma questão sensivel. Campinas, SP, Editora da Unicamp.

GOLDMAN, Marlene

2015 "Purging the World of the Whore and the Horror. Cothic and Apocalyptic Portrayals of Dementia in Canadian Fiction". In SWINNEN, Aagje e SCHWEDA, Mark (orgs.). Popularizing Dementia: Public Expressions and Representations of Forgetfulness. Aging Studies, vol.6. Alemanha, Transcript Verlag, Bielefeld, pp. 69-88.

LEIBING, Annette

2000 "Velhice, doença de Alzheimer e cultura: reflexões sobre a interação entre os campos da antropologia e da psiquiatria". In DEBERT, Guita Grin e COLDSTEIN, Donna M. (orgs). Políticas do corpo e o curso da vida. São Paulo, Ed. Sumaré.

RICOEUR, Paul

2007 A memória, a história, o esquecimento. Campinas, SP, Editora da Unicamp.

ROBBINS, Jessica C.

2008 'Older americans' and Alzheimer's disease: citizenship and subjectivity in contested time. University of Michigan. Disponível em http://quod. lib.umich.edu/cgi/p/pod/dod-idx/older-americans-and-alzheimersdisease-citizenship.pdf?c=mdia;idno=0522508.0017.104.

ROSE, Nikolas

2001 "The politics of life itself". Theory, culture \& society, 18(6):1-30.

ROSE, Nikolas e ABI-RACHED, Joelle

2013 Neuro: the new brain sciences and the management of the mind. Princeton, Princeton University Press. 
RUSSO, Jane A. e PONCIANO, Edna T.

2002 "O sujeito da neurociência: da naturalização do homem ao reencantamento da natureza". Physis Revista de Saúde Coletiva, 12 (2): 345-373.

SACKS, Oliver

1997 O homem que confundiu sua mulher com um chapéu - e outras histórias clínicas. São Paulo, Companhia das Letras.

SEIXAS, Jacy Alves de

2004 "Percursos de memórias em terras de história: problemáticas atuais". In BRESCIANI, Stella e NAXARA, Márcia (orgs). Memória e (res)sentimento: indagações sobre uma questão sensível. Campinas, SP, Editora da Unicamp.

SELICMANN-SILVA, Márcio (org.)

2003 História, memória, literatura: o testemunho na era das catástrofes. Campinas, SP, Editora da Unicamp.

SEVERI, Carlo

2007 Le Principe de la chimère: une anthropologie de la mémoire.

Paris, Éditions Rue d'Ulm-musée du quai Branly.

TAUSSIC, Michael

1993 Xamanismo, colonialismo o o homem selvagem: um estudo sobre o terror e a cura. São Paulo, Paz e Terra.

YATES, Frances A.

2007 A arte da memória. Campinas, SP, Editora da Unicamp.

WEARING, Sadie

2015 "Deconstructing the American family. Figures of parents with dementia in Jonathan Franzen's The Corrections and A.M. Homes' May We Be Forgiven". In SWINNEN, Aagje e SCHWEDA, Mark (orgs.). Popularizing Dementia: Public Expressions and Representations of Forgetfulness. Aging Studies, vol.6. Alemanha, Transcript Verlag, Bielefeld, pp.43-68.

BLOCS

http://living-with-alzhiemers.blogspot.com.br/

http://creatingmemories.blogspot.com.br/ 


\section{ABSTRACT}

The article discusses how memory is constituted in a tense and ambiguous relationship between imagination and hallucination, youth and old age, normal and pathological over of the Alzheimer's composition. If the bibliography shows how the process mnemonic does not unfold in a chronological way and linear, but as overlapping and entangled temporal, it is worth to ask when this process becomes pathological. From notions such as trauma, truth, factual, and hallucination, the article walks you through the different meanings, contexts and uses of memory.

\section{KEYWORDS}

Alzheimer's

Disease, Memory, Hallucination, Home, Time.

Recebido em 22 de setembro de 2016. Aceito em 31 de maio de 2017. 